\title{
Working or Shirking? A Closer Look at MPs' Expenses and Parliamentary Attendance ${ }^{*}$
}

\author{
Timothy Besley and Valentino Larcinese \\ London School of Economics and Political Science
}

$\mathrm{PEPP} / 15$

Political Economy and Public Policy Series The Suntory Centre

Suntory and Toyota International Centres for Economics and Related Disciplines

London School of Economics and Political Science Houghton Street

November 2005 London WC2A 2AE

Tel: (020) 79556674

\footnotetext{
* We are grateful to Christopher Hood, George Jones, John Lott Jr., Philip Norton and Riccardo Puglisi for useful comments and advice. Mitchell Young provided dedicated research assistance.
} 


\begin{abstract}
This paper studies determinants of MPs expense claims in Parliament using the data released under the freedom of information act in 2004. Using a multiple regression framework, we correlate expenses with three sets of variables: constituency characteristics, party affiliation and individual characteristics. We also look at the ratio of parliamentary expenses claimed to votes cast in parliament as a crude measure of value for money. We use the results to reflect on two views of the motivation of MPs, the public Choice view and the public service view.
\end{abstract}

\title{
Contents
}

1 Introduction

2 Background and Data

3 Empirical Method

4 Results

5 Conclusion

References

(C) The author. All rights reserved. Short sections of text, not to exceed two paragraphs, may be quoted without explicit permission provided that full credit, including $\mathbb{C}$ notice, is given to the source 


\section{Introduction}

In an era of greater calls for transparency and accountability in government, coupled with increasing media activism, the public and private lives of public officials receive ever greater scrutiny. One facet of this is the attention paid to the remuneration - direct and indirect - that such officials receive. A case in point is the scheme that provides expense allowances to MPs in the U.K. which supplement their salaries. On the 21st of October 2004, just before the Freedom of Information Act come into force, the House of Commons made public the detailed accounts of individual Members of Parliament's expense claims for the first time.

This increase in transparency led to a flurry of newspaper articles and opinion polls which did their best to cast MPs in an unfavourable light. For example, the Daily Mail was quick to use the label "Westminster gravy train" to describe such allowances. ${ }^{1}$ Outrage was caused by both the total amounts and a number of allegedly unjustified claims. Several cabinet members, for example, claimed the allowance for a London home, despite receiving grace-and- favour accommodation by the government. Opinion polls taken immediately after this coverage demonstrated a negative public perception of such expenses. ${ }^{2}$

Sir Archy Kirkwood MP, spokesman for the House of Commons Commission - the body that approved the publication - mounted a robust defence arguing:

[publishing MPs' expenses was] "a significant step towards openness and accountability that would allow taxpayers to see how their money was being spent.... These tables show essential expenses needed by politicians to operate in a fast-moving, high-pressure environment. Members are like 659 individual small businesses, working under an ever-increasing load and more complex environment. They now deal with issues, and communicate in ways unheard of a few years ago. They require more back-up staff, more computer resources, and more allowances to enable them to travel back and forth to Parliament, living away from

\footnotetext{
1 "So is your MP worth Pounds 175,000?", Daily Mail, 22nd October 2004

${ }^{2}$ For example, a YouGov poll carried out for the Mail on Sunday on October 22-23 2004 found that $82 \%$ of respondents believed that MPs were allowed to claim too much by way of allowances - see http://www.yougov.com/archives/pdf/DBD040101010_2.pdf
} 
home for days at a time, while keeping in touch with the problems and issues of their constituents."

Individual MPs singled out as "high claimers" similarly defended the legitimacy of these expenses, one claiming that "this is not about trousering a lot of money. This is about the money it takes to do the job". " Claire Curtis-Thomas, who topped the list with expenses of $£ 168,889$ said: "we don't know whether to be worried or to be honoured. We have got eight people working in our office, and during the course of last year visited all 33,000 homes in the constituency and held street surgeries". 4 The general point is that high expenses might simply be a reflection of the need to provide MPs with the resources needed to deliver a high quality service to the nation and their constituents.

This paper conducts a statistical analysis of MPs' expenses using three years of data between 2001 to 2004. The analysis has three goals. First, we assess the relationship between expense claims and structural features of the constituencies they represent, such as the distance from London, the size of the constituency and the income level of constituents. In trying to assess which MPs are really "high spenders", it is necessary to control for these observable characteristics of constituencies. Second, we examine whether differences in political circumstances affect expense claims. This includes party effects, the marginality of the constituency and the party the MP represents. Since these variables are not structural, they are likely to represent behavioural effects, i.e. decisions made by MPs to affect re-election chances, to serve constituents better or to further self-interest. Third, we look at how personal characteristics affect expense claims. These include age, educational background and how long an MP has served for. The last two variables represent largely behavioural factors and give us further insight into the choices MPs make. By using a multiple regression framework, we are able to look at the relative significance of these different factors while controlling for the others.

We then look at whether MPs have announced they will retire at the next election. The U.S. literature on legislators' performance has put a lot of weight on such announced retirements as a means of testing whether legislators are inclined to "shirk" when they are about to step down from

\footnotetext{
${ }^{3}$ Stephen Pound, Ealing North MP, reported in "Average MP's expenses cost taxpayer pounds 118,000, The Guardian, 22nd October 2004.

${ }^{4}$ UK's costliest MP says she is worth every penny, The Guardian, October 22, 2004.
} 
elected office. If what keeps an MP "honest" is the prospect of re-election then this should lead to more expenses being claimed. If such MPs perceive less of a need to invest in constituency service, then announcing retirement should be correlated with lower expense claims.

Finally, we turn to particular performance measures of MPs based on their attendance record in Parliament in addition to their expense claims. We compute the amount of expenses that a MP claims relative to the number of votes they cast in Parliament over the period in question. This cost per vote varies significantly across MPs, reflecting a combination of variations in attendance and in expenses claimed. The former varies significantly with a few MPs attending fewer than $10 \%$ of possible divisions while others attend more than $90 \%$ of the time. Retiring MPs are significantly less likely to vote in Parliament.

Using cost per vote as a measure of value for money, we find that there are differences across parties and that the cost per vote varies with both age and experience. More experienced MPs charge considerably more in expenses for every vote they cast in Parliament; however, for a given experience, younger MPs are more expensive. While acknowledging that this is only a single dimension of MP performance, it is a relevant consideration for the public at large who have to fund Parliament out of the taxes they pay.

These discussions go to the heart of more general debates about standards in public life and the motivations of politicians. On the one hand is a tradition that emphasizes the motives for holding office as based on an ethic of public service where representatives are faithful, honest and competent. Such competence is enhanced if a legislature is adequately professionalized, which means providing suitable support for research and constituency service. On the other, politicians are viewed in the Public Choice tradition as self-interested using the state as vehicle for achieving private ends. ${ }^{5}$ The provision of expenses is then viewed as just another dimension of rent-seeking behaviour.

Overall, the results provide qualified support for a relatively benign view of MPs expenses. The main factors that shape decisions in a predictable way are structural features of constituencies. However, we also find that political characteristics and personal characteristics matter some of the time. Having

\footnotetext{
${ }^{5}$ This view has greatly influenced studies of U.S. Congressional politics following the classic study by Mayhew (1974) which cast Congressman as "single-minded seekers of re-election" (page 5).
} 
decided to step down as an MP affects the decisions both to claim expenses and to vote in Parliament.

The remainder of the paper is organized as follows. The next section discusses the data and some basic facts. Section three discusses the empirical method and results. Section four offers some concluding comments.

\section{Background and Data}

The package offered to MPs consists of a salary and a series of allowances aimed to enable their attendance at Westminster and to improve their effectiveness as public servants. The basic MP's salary is around £59,000 per annum. ${ }^{6}$ This amount is supplemented by expense allowances - up to $£ 77,000$ on staff costs and nearly $£ 20,000$ on running their offices. If their constituency is outside inner London they can also claim more than $£ 20,000$ pounds to cover the cost of a second home. In addition, there is a budget for IT support of $£ 3000$ as well as coverage of certain incidental expenses. Travel expenses between Westminster and the constituency are reimbursed at 56.1p a mile ${ }^{7}$ which is somewhat more generous than the Inland Revenue recommended rate of $40 \mathrm{p}$ a mile. Moreover, some private companies pay only $25 \mathrm{p}$ a mile.

MPs for neighbouring constituencies often claimed very different amounts. MP Anne Picking from East Lothian, for example, claimed £39,744 in travel expenses, while neighbouring MP David Hamilton, from Mid-Lothian, claimed $£ 18,833$. Analogous, apparently inexplicable, differences can be found across all types of claims. ${ }^{8}$

\footnotetext{
${ }^{6}$ Members of the government received additional salaries.

${ }^{7}$ More precisely, MPs could claim 56.1p per mile for up to 20,000 miles (25.9p thereafter) when travelling on parliamentary business in 2003-2004. There was also a bicycle allowance of $7.2 \mathrm{p}$ per mile. If using public transport, MPs were reimbursed first class train tickets and flights. It was also possible to be reimbursed the expenses of up to three visits to EU institutions or to national parliaments of EU members. To the total MP travel spending variable, that is reported as Member Travel, we add the Members' Staff travel, which consists in expenses incurred by the Member and all his/her employees when travelling between Westminster and the constituency. There are limits to the number of such trips that are reimbursed: these consisted in 18 single journeys per year until December 2003, and in 30 single journeys for the period from 1 January 2004 to 31 March 2005.

${ }^{8}$ The statistical analysis includes regional indicator variables to account for basic regional differences in transport and living costs.
} 
Our main source of information is the list of expenses claimed by MPs and published under the Freedom of Information Act (2000) in October 2004 by the House of Commons. These consist of three data sets, one for each fiscal year from 2001-2002 to 2003-2004. Since we do not have any time variation in other data, our analysis averages the observations across the three years, to smooth possible idiosyncrasies due to particular circumstances.

We exclude MPs from Northern Ireland from our analysis. The political situation has certainly many peculiarities there if compared with the rest of the country. More importantly, however, the four MPs from Sinn Fein claimed expenses in line with other MPs despite not taking their seats in Westminster. The specificity of this situation, whatever opinion one has on the matter, suggests we should exclude these few observations from Northern Ireland from our regressions. In addition, we have excluded constituencies that have had by-elections (and therefore changed their MP) during the period under consideration. This leaves us with a sample of 638 MPs.

Table 1 gives the summary statistics for our data. Averaged over the three years for which we have data, the median (and mean) amount of expenses claimed is just under $£ 106,000$ with a standard deviation of around $£ 12,000$. Regional differences are significant with spending levels being lowest in London (an average of $£ 98,000$ ) and highest in the south, north, northwest and Scotland $(£ 110,000) .{ }^{9}$ From these data we know the constituency and the party of each MP. While there are suggestive differences in allowances claimed by different party members, they are not statistically significant. ${ }^{10}$

The analysis uses allowances disaggregated into sub-categories. This makes sense since something like travel seems likely to be driven mainly by distance from Westminster whereas others are affected more by an MP's behaviour. We focus separately on travel expenses as well as on staff expenses (the largest category with a mean value of nearly $£ 59,000$ ), which also attracted serious attention. We also focus on expenses that have been relatively less under the spotlight, i.e. expenses net of staffing, travels and London accommodation expenses. This residual variable, that we will refer to as "other

\footnotetext{
${ }^{9} \mathrm{~A}$ detailed description of all variables, as well as summary statistics, are reported in the Appendix.

${ }^{10}$ This shows the importance of using proper statistical methods rather than the type of casual empiricism that is typical of journalistic accounts. For example, The Sun, trumpeted that "it also emerged that 16 of the top 20 with their snouts in the trough are Labour" suggesting that party differences might be significant.
} 
expenses", includes what in the original data set released by the Parliament is indicated by Incidental Expenses Provision (IEP), Centrally Purchased Stationery, Postage, Centrally Provided Computer Equipment and Other Costs. ${ }^{11}$ These expenses are less obviously linked to specific observable needs and are therefore more manipulable: we think that analysing them separately can provide useful insight into the behaviour of MPs.

We regress expenses on a number of MPs' covariates that try to capture the characteristics of their constituency, some basic political variables and their own individual characteristics. This analysis reveals a number of significant patterns. However, we will argue that focusing only on expenses, as the press has done, can be misleading. After all, allowances serve, in principle, to facilitate the work of MPs and to ensure a level playing field across MPs from differing constituencies. We should take into account the amount of work delivered by an MP before expressing any normative statement. There is obviously no perfect measure to assess the overall performance of an MP and the services delivered to the constituents. Here, we look at the rate of attendance at parliamentary meetings. ${ }^{12}$ Although MPs have to fulfil numerous tasks, one of their main duties is to represent their constituents in Parliament and, therefore, to participate in parliamentary debates, other proceedings and voting processes. In the period we study, MPs attended on average only $69 \%$ of possible divisions. However, there is considerable variation across MPs. We show that the variation in parliamentary attendance can be explained by many of the variables that also explain expenses claims.

We argue that, rather than using expense claims, a better measure of how well public money has been spent is to measure the cost per vote in parliament. This is obtained by dividing the total expenses claimed over the three year period by the total number of votes. The average cost per vote is $£ 556$ with considerable variation across MPs. By using this measure we conclude that only four variables matter in this crude measure of "value for money": party affiliation, cabinet membership, age and seniority in parliament.

\footnotetext{
${ }^{11}$ IEP meets the costs of the MP's office or surgery (including accommodation, equipment etc.), as well as work commissioned or other services, including some travel and communication expenses. Under "Other" we have a number of possible costs, including temporary secretarial allowance (which pays for additional help when members of staff are absent because of sickness or maternity leave), contributions to security costs for the office etc.

${ }^{12}$ Attendance is measured by the number of votes (divisions) cast in the period considered.
} 
Table 1 contains information about the constituencies and characteristics of MPs. The average age of an MP is 50 and average experience eight years. It is striking that $26 \%$ of MPs are Oxbridge educated. Nearly $18 \%$ are women. Around $13 \%$ stepped down at the end of the Parliament elected in 2001.

Politicians often seek to be re-elected. Indeed, the main sanction available to voters who are unhappy with their MP is to vote them out. If this mechanism has any force, we should expect MPs to be less "well-behaved" once it is clear they will not stand again. At the other end, there is a view that says elections are mainly a selection device to sort in publicly-spirited politicians. If it succeeds in this task, there should be no difference in their performance once the electoral sanction is removed.

A substantial literature has grown up testing these ideas and looking at whether politicians behave differently after they have decided to retire from politics. Lott and Bronars (1993) analyse Congressional voting data from 1975-90, and find no significant change in voting patterns in a representative's last term in office. They use this to argue that selection works well for the U.S. Congress, leading to individuals who are well aligned with constituents interests. Further evidence on the U.S. Congress is found in McArthur and Marks (1988), who observe Congressional behaviour in a lame duck session of Congress: in post-election sessions, members who have not been re-elected are at times called upon to vote on legislation before the swearing in of the new Congress. They find that retiring representatives were significantly more likely in 1982 to vote against automobile domestic content legislation than were members who were returning. Besley and Case (1995) find that policies are different in states when U.S. state Governors cannot stand again for election because of the imposition of term limits.

We are not aware of any previous study that addresses these issues for the U.K.. In this context, the role of parties is much more important than in the U.S.. Constituency pressures instead are probably less important. Hence, we might expect party discipline to override any tendency to "shirk" towards the end of a political career. Here, we analyse whether MPs who announced their intention to step down at the end of the Parliament behave differently from those that will face re-election. We find that retiring MPs both claim fewer expenses and vote less. This second result is consistent with some previous findings in the U.S.; Lott (1987) and Lott and Reed (1989) find that US House members miss more votes in their last term in office, although they do not change their voting patterns. Our finding that retiring MPs spend less is the 
opposite of what has been found for the US Congress by Parker and Powers (2002), who find that retiring legislators spend substantially more money in foreign travel than their colleagues. We do not find any effect of retirement on the cost per vote. This suggests that the reduction in expenses claims is explained by lower attendance rather than by increased rent-seeking.

Our results are also relevant to the small literature on the effectiveness of legislators. The main measures of effectiveness used are typically related to "entrepreneurship" (i.e. the number and relevance of bills sponsored by a legislator), as in Shiller (1995) and Wawro (2002) or to subjective assessments of legislators made by journalists and lobbyists, as in the works of DeGregorio (1997) and Padro' i Miguel and Snyder (2004). This literature points clearly to the role of seniority and party affiliation as important explanatory variables of effectiveness: more senior members and members of the majority party tend to be more effective legislators. In their analysis of the North Carolina House of Representatives, Padro' i Miguel and Snyder (2004) show that the impact of seniority can be due to both selection and learning by doing. Our results on the U.K. parliament confirm the importance of party affiliation and seniority although, in our case (and possibly because of the different measure of effectiveness that we adopt), more experienced MPs turn out to be less cost effective for citizens.

Looking at MPs' expenses brings into sharp relief the issue of what is socially valuable about what they do. There is a large literature on constituency service by British MPs and its determinants. One of the main debates has been whether individuals MPs have any incentive to invest in their electorates given the importance of parties on voting decisions. Cain, Ferejohn and Fiorina [1984], argue persuasively that the British system does result in an increase in their personal vote. They study this using polling data and based on interviews with MPs. It is widely agreed in this and other studies that holding regular surgeries to deal with constituent's needs is a key part of such service. ${ }^{13}$ Moreover, there appears to be considerable heterogeneity in the propensity to do so (over time and space). Engaging in correspondence with constituents and with ministers on their behalf is also an important aspect of such service. Postage charges by MPs may be a proxy for such activity.

\footnotetext{
${ }^{13}$ See Norton and Wood (1993) for an excellent overview of constituency service by MPs.
} 


\section{Empirical Method}

The purpose of this study is not to establish whether there have been abuses of the allowance system. Only careful investigation of individual claims could ever identify these. Rather, we ask if there is any systematic correlation between the observed expenses and specific characteristics of the constituencies and/or of the individual MPs. We are interested to see how much such expenses claims can be justified by objective needs (for example the distance from Westminster), by activism and service to constituents (in the form of voting in the House of Commons), or by other types of political and electoral motivations.

Our basic empirical specification is as follows:

$$
a_{m c r}=\alpha_{r}+\beta y_{c r}+\gamma x_{m c r}+\delta z_{m c r}+\varepsilon_{m c r}
$$

where $a_{m c r}$ is the allowance claimed by MP $m$ in constituency $c$ in region $r$. We include region dummy variables $\alpha_{r}$, constituency characteristics $y_{c r}$, political variables $x_{c m r}$ and individual MP characteristics $z_{m c r}$. We estimate this equation using OLS with standard errors robust to heteroskedasticity of an arbitrary kind.

We consider first total average expenses for the period 2001-04. We then take a closer look at travel and staff expenses, that attracted serious criticism by most of the press. Most of the travels of MPs are made between Westminster and their electoral constituency: thus, the main explanatory variable for travel expense claims should be the distance of the constituency from Westminster: for this purpose we have calculated road distances in miles as reported by the Automobile Association. Staff expenses should instead mainly be driven by the local cost of labour, assuming that most employees would come from the same constituency of the MP. The average constituency income should represent an important explanatory variable. However, staff expenses show limited variation when compared to other categories, with most MPs tending to spend amounts close to the maximum allowance. We then turn to the "other expenses" variable described in the previous section. As opposed to the previous cases, there are no obvious variables to explain the variability of such spending categories, which probably makes it easier for MPs to use them either as personal perks or to deliver a better service to the constituents. In either case, the usage of such claims should make clearer the motivations of the politicians. 
To test whether the prospect of re-election affects the behaviour of current MPs we will then consider the following specification:

$$
a_{m c r}=\alpha_{r}+\beta y_{c r}+\gamma x_{m c r}+\delta_{1} z_{m c r}+\delta_{2} r_{m c r}+\varepsilon_{m c r}
$$

where $r_{m c r}$ is a dummy variable equal to 1 for MPs who, at any point during the legislature, announced their intention not to stand at the next general election. If expense claiming is driven by the desire to pocket public money then $\delta_{2}$ should be positive, since the claimant will not face the same sort of public scrutiny as a standing candidate. A negative sign of $\delta_{2}$ would instead signal a relationship between expense claiming and the desire to enhance the perspectives of re-election, which could be related with the quality of the service delivered to the constituents.

We analyse MPs participation in parliamentary affairs by estimating an equation of the form

$$
p_{m c r}=\alpha_{r}+\beta y_{c r}+\gamma x_{m c r}+\delta_{1} z_{m c r}+\delta_{2} r_{m c r}+u_{m c r}
$$

where $p_{m c r}$ is the participation ratio in Westminster meetings, measured by using parliamentary voting records. If $p_{m c r}$ is equal to 1 then MP $m$ in constituency $c$ and region $r$ cast his/her vote in all bills passed during the period considered, if it is zero then he/she never cast a vote. Our measure of the "cost per vote", $b_{m c r}$, defined as $\left(a_{m c r} / p_{m c r}\right)$ multiplied by the total number of divisions held. We therefore run a regression of the form:

$$
b_{m c r}=\alpha_{r}+\beta y_{c r}+\gamma x_{m c r}+\delta_{1} z_{m c r}+\delta_{2} r_{m c r}+u_{m c r} .
$$

This equation combines information about attendance and expenses together. For example, retiring MPs may attend less and claim fewer expenses in which case they will not be "more expensive" in cost per vote. There are arguably other ways to measure the performance of elected representatives and we certainly will not claim that the work delivered by an MP is all captured by the number of votes cast in Parliament. Nevertheless, our measure captures an important aspect of parliamentary work and has the advantage of being easily and objectively measurable. More work should certainly be devoted to construct better measures of effectiveness but we believe that, using the cost per vote, we can start providing an important insight on the performance of MPs. 


\section{Results}

\subsection{Total average expenses}

Table 2 reports the regression results when the dependent variable is total average expenses in the 3 years considered. The specification in the first column includes only constituency characteristics, namely the distance from Westminster, the average income in the county and the size of the electorate. As expected, the distance has a positive and significant sign while both income and size turn out to be insignificant.

Column 2 introduces political variables. Party affiliation is not correlated with the total expenses claimed by MPs. Coming from a marginal constituency (i.e. where the distance between the winner and the runner up in the 2001 election was less than 10\%) is also uncorrelated with expenses.

Cabinet members claim fewer expenses than other MPs. This makes sense given that some of their expenses are paid separately. Moreover, their commitments with the executive leave them less time to devote to parliamentary business. We find instead no significant impact of shadow cabinet membership.

Constituencies with higher voter turnout rates tend to have higher expense claims. This result is robust and holds up across a variety of specifications. Interpreting this result requires some understanding of what drives turnout. If high turnout is driven purely by ideological attachment then a higher spending could be a symptom of a lack of accountability. However, if turnout indicates informed participation then high spending indicates something rather different. One possibility is that an electorate that participates more requires more attention from their MP. The fact that we control for the marginality of the seat (which is a proxy for contestability and, therefore, accountability) suggests that the second interpretation is more plausible. Although it is hard to establish convincingly, this second interpretation relates to Putnam's (1993) study of Italian regions. Putnam claims that the effectiveness of governments in reflecting the preferences of their citizens can be related to social engagement and political participation. The correlation between political participation and the quality of governance in Italian regions has recently been confirmed by Solt (2004).

In column 3 we present the results for the complete specification, when all the explanatory variables are used. We now introduce individual characteristics of MPs, i.e. their age and sex, their experience (i.e. the length of 
their service as MPs measured in years), a dummy equal to 1 if they have a university degree and, finally, a dummy equal to 1 if their degree is from either Oxford or Cambridge ${ }^{14}$. While the gender and having a degree do not appear to be correlated with the amounts claimed, other personal characteristics seem to have a relevant explanatory power. In particular older and more experienced MPs claim less, and each one of these two variables appears to have an independent impact (although the experience variable is significant only at the $10 \%$ level). ${ }^{15}$ Degree holders do not behave differently from the rest, but graduates of either Oxford or Cambridge spend less. Whether this is a reflection of their more privileged backgrounds or some kind of enhanced sense of responsibility is moot.

If we want to quantify the magnitude of the various effects, by using the results of column 3 we can say that each extra mile distance from Westminster translates into approximately £31.8 per year of expenses claim, while being a cabinet member induces, when controlling for other factors, an average claim reduction of almost $£ 9,000$ per year when compared with other MPs. Each additional year of age or experience reduces spending by, respectively, 2283 and $£ 149$, while graduates from Oxford or Cambridge spend on average more than $£ 2,500$ less than the rest.

Some of the variables we have used to explain expenses are related to objective measures of need. Therefore, reporting how much an MP claims without taking into account at least some of such needs can be misleading. A better way to identify high spenders is instead to look at the residuals of the regression analysis, i.e. the unexplained spending component.

Table 3 reports the unconditional top 10 spenders, where the amount has been calculated as an average over the period considered. In table 4 we report instead the top 10 spenders as they emerge from our regressions, i.e. using the residual as a measure. In the first column of table 4 we report the top 10 spenders when conditioning on constituency characteristics alone, the minimum measure of need. Column 2 reports the top 10 spenders when conditioning on both constituency and political characteristics, while in

\footnotetext{
${ }^{14}$ Oxford and Cambridge have a strong prominence in British political life. It is probably sufficient to mention that 25 British Prime Ministers have been educated at Oxford and 13 at Cambridge. Such prominence has induced us to single out these institutions from the other British universities.

${ }^{15}$ This could be regarded as more efficiency in the use of resources by part of more experienced MPs. In fact, the analysis of participation in parliamentary divisions will lead us to a rather different conclusion.
} 
column 3 we condition on all the variables used in the regressions of Table 2. The names listed appear to be consistently similar in all cases: five of the top unconditional spenders of Table 3 appear also in all columns of Table 4 (Claire Curtis-Thomas, Paul Farrelly, Doug Henderson, Eric Joyce and Mohammad Sarwar). There are, however, some noticeable exceptions. Andrew Dismore is 25 th in the unconditional list but always in the top four in the conditional columns. Andrew Rosindell also appears in all conditional lists but is 17th in the unconditional list. Some MPs appear in Table 4 despite being well out of the spot-light in their unconditional spending (Jacqui Lait, Austin Mitchell and Barry Gardiner, ranked respectively 56th, 59th and 67th in unconditional spending). On the other side, some MPs are among the top spenders for reasons that are well captured by our explanatory variables. Alistair Carmichael, for example, is 9th in the unconditional expense ranking but becomes 131st when conditioning on constituency characteristics and 166th when all the covariates of Table 2 are used. Again, this suggests that plenty of caution should be used when expressing an evaluation of crudely exposed expense claims.

\subsection{Travel, staff and other expenses}

We now look at disaggregated spending. This makes sense since different types of spending are subject to different rules and are likely to respond differently to constituency characteristics.

We begin with travel expenses, which appear to be mainly predicted by constituency characteristics, with distance from Westminster having a positive impact and income and size having a negative impact. Other significant effects are represented by the constituency turnout rate (positive) and being a member of the cabinet (negative). Party membership and personal characteristics appear to have no impact with the important exception of sex; women MPs tend to spend less on travel, other things equal. The estimated saving compared with male MPs is approximately $£ 1,000$ per annum. This regression exhibits a relatively high $\mathrm{R}$-squared, indicating that the variables we use can explain approximately two thirds of the variation in travel spending.

Staff spending presents us with a different picture. ${ }^{16}$ Distance is again

\footnotetext{
${ }^{16}$ Members of Parliament could spend up to $£ 77,543$ on staff costs in 2003-04. As noted before, however, staff expenses show limited variation when compared to other categories.
} 
statistically important, although it is now only significant at the $10 \%$ level. It is possible that increased distance from Westminster also requires increased staff support. Contrary to expectations, local average income and the size of the constituency do not appear to have an impact on staff expenses. However, the party affiliation of the MP matters. While Conservative and Labour party membership do not significantly differ, Liberal Democrat MPs tend to spend more than them (an average of almost $£ 1,500$ ) while other parties (mainly the SNP and PC) tend to spend less (almost £4,000). However, the latter coefficient is significant only at the $10 \%$ level. Age turns out to be correlated with expenses - older MPs spend less on staff. The correlation with gender is not significantly different from zero.

Finally, column 3 turns to "other expenses". From the summary statistics of Tab. 1, it is clear that this variable is more dispersed than total and staff spending. Only travel spending displays a higher variation but, as we have seen, this is simply because of the high variability of the distance from Westminster of the various constituencies.

Column 3 delivers significant results and new insight into the role played by our explanatory variables. First, constituency characteristics do not have any impact on the usage of these allowances. There appears instead to be a clear difference in parties. Labour and Liberal Democrat MPs spend on average more than Conservatives and other MPs. The corresponding coefficients are highly significant, with Labour and Liberal Democrats spending, respectively, an average of $£ 2,500$ and $£ 1,500$ more than the Conservatives. Older and experienced MPs also spend significantly less - an increase of one standard deviation in the MPs age (8.6 years) implies approximately $£ 1,100$ lower spending in this category. The corresponding figure for experience (and controlling for age) is approximately $£ 800$.

The picture that emerges from Table 3 shows that there are differences in the determinants of the various spending items. Travel expense claims appear to be mainly driven by objective needs, linked with constituency characteristics, in particular the distance between Westminster and electoral constituencies. For staff and other expenses, party affiliation and the age and experience of an MP matter. The Liberal Democrats seem to be high spenders on staff while Labour MPs spend more on other items. The Conservatives appear to be lower spenders. Age and experience reduce spending, especially other expenses.

This picture is, however, mainly descriptive, and certainly not sufficient to express any normative evaluation. We will make an attempt in that direction 
when we study participation patterns and the cost per vote.

\subsection{Do retiring MPs behave differently?}

It is well established in the political economy literature, at both the theoretical and empirical levels, that the perspective of facing re-election may induce a different behaviour in politicians. In our case, retiring MPs are, to a certain extent, less constrained by their relationship with constituents as compared to MPs that will stand again. This could make a difference, although in principle it is not clear in which direction. Retiring MPs face a reduced incentive to satisfy public morality (and therefore should spend more) but also fewer incentives to be active in political terms (and this should lead to less spending). If allowances are genuinely used to improve MPs activity then we should not observe any increase in spending by retiring MPs: on the contrary, we should expect a decrease.

Table 6 introduces a dummy variable which equals one if MPs announce their intention to step down at the end of the Parliamentary term. The results show that this variable has generally a negative sign on expenses ${ }^{17}$ but it is only statistically significant in explaining the Other expenses category (see column 4).

Thus, in general, the difference between standing and retiring MPs can be found mainly in items like computer equipment, stationery and postage. Some of these items can be linked with the need to maintain good contact with voters. The sign of this coefficient is negative. Thus the prospect of reelection does appear to induce MPs to spend more. This is consistent with the idea that money is spent in political activities rather than misappropriated. The experience variable becomes less significant in this specification, as it is correlated with the intention to step down.

\subsection{Parliamentary attendance and the cost per vote}

The main purpose of providing MPs with spending allowances is arguably that of improving the quality of the service to their constituents. Having established that there are some specific individual and systemic characteristics that affect expense claiming, it is therefore important to determine whether

\footnotetext{
${ }^{17}$ It is positive but not significant in the travel expenses equation.
} 
such expenses correspond to the amount of effort expended by MPs. Parliamentary attendance is the minimum that constituents can require from their representatives. Hence, we will use this variable to measure the amount of work delivered by MPs.

We start therefore by constructing a variable that represents the percentage of divisions for which the MP cast his/her vote in parliament. A total of 876 divisions were held during the period we consider ${ }^{18}$. The attendance variable goes therefore from zero to a theoretical maximum of 100 if an MP voted in every division. ${ }^{19}$

The first column of table 7 reports the OLS coefficients of a regression in which the percentage of attendance is the dependent variable and constituency, political and individual characteristics are used as explanatory variables. From this exercise we obtain a number of significant results. First, Labour MPs have a much higher propensity to vote. Controlling for all other variables, an average Labour MP tends to vote in Parliament almost $6 \%$ more than a Liberal Democrat MP, 9\% more than a Conservative MP and 15\% more than an MP from another party. This is particularly striking as the Labour party had a large majority in the parliament that we are studying. Not surprisingly, cabinet members vote less than other MPs while female MPs tend to vote less than their male colleagues, although only by a little less than $3 \%$ on average. Experience reduces participation; a one standard deviation in experience reduces voting by approximately $4.3 \%$. This effect is of the same order of magnitude as the reduced participation for MPs who do not intend to stand again at the next election.

It is clear that some variables affect both voting and the amount of expenses claimed. Thus, looking merely at parliamentary expenses to evaluate the behaviour of politicians can be misleading. A better measure to look at would be one that takes into account the extent of attendance. Thus we compute the cost per vote in Parliament for each MP by dividing their total expenses by the number of times that they voted. Excluding the basic salary, which is the same for all MPs, this measure is derived by dividing the total expenses claimed during the three years considered, by the number of divisions voted during the same period (876). We obtain that the average cost of an individual vote in parliament is $£ 556$. This figure, however, hides

\footnotetext{
${ }^{18}$ There are often several divisions during Report stage of a bill (and during committee, if taken on the floor of the House). Not all votes take place on legislation.

${ }^{19}$ The speaker and deputy speakers are excluded from this analysis.
} 
a large variation: the cost goes from $£ 257$ for the cheapest MPs to $£ 3,360$ for the most expensive. While the performance measure is crude, it is probably no cruder than the kinds of performance measures that MPs themselves have regularly voted to impose on other areas of the public sector. It would, of course, be good to collect other data on MPs activism in future to further assess how much the public is getting "value for money".

Table 8 reports the top 10 most expensive MPs according to this criterion, and the corresponding cost per vote. Not surprisingly, column 1 shows that the most expensive votes in parliament, i.e. the highest ratio of expenses over attendance, are those of members of the executive, with the Prime Minister being the most expensive of all. In column 2 we report the same list excluding members of the government (not only of the Cabinet). If compared with the table of unconditional total expenses, we have a number of new names on the list. In brackets we report the position of each MP in the unconditional ranking of expenses. George Galloway has the highest ratio of claims per vote among non-government members, even though he was only 333th in the list of expense claims. Further down the list, we encounter both MPs that were high in the expense ranking as well as MPs who passed totally unobserved, being in the middle or even rather low in that list.

In columns 2, 3 and 4 of Table 7 we estimate regressions where the cost per vote is used as the dependent variable. From columns 2 and 3 it appears that constituency characteristics and most political variables do not affect cost per division attended. Exceptions to this result are, as expected, cabinet membership and, more surprisingly, party affiliation. The cost of a vote in parliament by a Conservative or a member of another party (mainly SNP and PC) is well above the cost per vote of Labour or Liberal Democrat MPs. This result is confirmed even in column 4, when we control for individual characteristics. According to this last set of coefficients, each vote attended by a Conservative MP costs the taxpayer about $£ 58$ more than a vote attended by a Labour or Liberal Democrat MP. For SNP and PC this figure rises to £123. Members of cabinet are also expensive: each vote is $£ 545$ more costly than that of other $\mathrm{MPs}^{20}$.

\footnotetext{
${ }^{20}$ The reimbursement of travel expenses has, more than in the other cases, the purpose of facilitating attendance at parliamentary meetings. Hence, in separate regressions (not reported) we consider the cost per vote when only travel expenses are included. The results present some differences, and in large part mirror the results we already found in the expenses equations. In particular, the coefficients of constituency income and sex become negative and significant while those of age, conservative MPs, and cabinet members
} 
Coming to individual characteristics, we find no impact of gender or education and no different behaviour by retiring MPs. Only age and experience matter, although this time they go in different directions. Older MPs, keeping constant the time already spent in parliament, spend less for each vote delivered. One standard deviation in age implies a decreased cost of $£ 28$ per vote. On the other side, if we take two MPs of the same age but with different times spent serving in parliament, the more experienced MPs are also the more expensive. The magnitude of this effect is relatively high, an increase of one standard deviation in experience implying an increase of $£ 51$ in the cost of a vote.

This suggests that, on this metric, younger and less experienced MPs give the same work (in votes cast) at the same price. For every year that an MP stays in parliament, it appears (on average) that it costs $£ 10$ for every parliamentary vote they cast. There may, of course, be other compensatory benefits that come from having older and more experienced MPs which outweigh the rather narrow performance metric we have looked at.

Putting these results together, we can contrast the cost per vote of a 30 year old Labour MP who has just entered the Parliament with a 60 year old Conservative MP with 30 years experience. Our results suggest that the latter will (on average) claim around $£ 350$ more in expenses per division attended compared to the former. To put this result in perspective, this is an increase in the cost per vote of more than $60 \%$ of the mean cost. If the latter comparator were from the SNP, the figure would be around $£ 420$ more per division attended.

\section{Conclusion}

The question of whether MPs allowances help to deliver an effectively functioning legislature is both interesting and important. The popular press were quick to cite expense claims as part of a Westminster gravy train. But there are many benign factors that shape expense claims which need to be controlled for before jumping to conclusions. Our study suggests that, when reporting expenses in future, there should be some effort to do so making

become insignificant. This indicates that both cabinet members and conservatives MPs do not overspend in travelling and that that the reduction in cost per vote associated with age is not driven by less travelling but rather by reduced usage of other items. 
due allowance for objective features of constituencies. ${ }^{21}$

We find that constituency characteristics (such as distance from Westminster) do predict expense claims. This reinforces the point that expenses level the playing field between MPs with different circumstances. However, we also find some unexpected results that require more investigation. They include the patterns of party differences and the significance of constituency level turnout in predicting expense claims. Of the individual characteristics, we find understandable patterns in age and experience. The fact that Oxbridge educated MPs spend less is less easily explicable. Our findings for retiring MPs also merit further study.

The metric of cost per division attended yields particularly interesting findings. Here, the political life-cycle was shown to be important. There are also substantial differences between the parties in the expenses charged compared to attendance in Parliament. While there may be good reasons not to vote - especially in a Parliament where one party has a large majority - it is a matter of public interest to monitor all aspects of the performance of public servants and to assess the value for money they offer.

One undoubted reaction to our analysis will be in terms of the narrowness of the perspective that we have taken in terms of evaluating MPs' performances. However, many who make their livelihood in the public services will recognize in this a parallel with many recent efforts by parliament to regulate public services. This has focused on a few easily measurable targets that sometimes have questionable merit and have been argued to divert attention away from what really matters. Up until now MPs have not themselves been subject to performance targets. But this does raise the wider issue of whether (as public servants) they should. In this regard, one thing is certain - we now have the data to help implement them.

\footnotetext{
${ }^{21}$ This is similar to the argument that value added scores are more relevant than exam scores in assessing school performance.
} 


\section{References}

[1] Besley, Timothy and Anne Case, [1995b], "Does Political Accountability Affect Economic Policy Choices? Evidence From Gubernatorial Term Limits, Quarterly Journal of Economics 110(3), 769-98.

[2] Cain, Bruce E., John A. Ferejohn and Morris P. Fiorina, [1984], "The Constituency Service Basis of the Personal Vote for U.S. Representatives and British Members of Parliament," The American Political Science Review, 78(1), 110-125.

[3] De Gregorio, Christine A. (1997): Networks of Champions. Ann Arbour: University of Michigan Press

[4] Firth, David and Arthur Spirling (2003): TAPIR: Technique for Accessing Parliamentary division Information in $\mathrm{R}$. Contribution to the online $\mathrm{R}$ programming archive.

[5] Lott, John R. (1987): Political Cheating, Public Choice, 52, 169-187.

[6] Lott, John R. and R.W. Reed (1989): Shirking and sorting in a political market with finite-lived politicians, Public Choice, 61, 75-96.

[7] Lott, John R., Jr. and Stephen G. Bronars, [1993], "Time Series Evidence on Shirking in the U.S. House of Representatives," Public Choice, $76,125-49$.

[8] Mayhew, David, [1974], Congress: The Electoral Connection, New Haven: Yale University Press.

[9] McArthur, John and Stephen V. Marks, [1988], "Constituent Interest vs. Legislator Ideology: The Role of Political Opportunity Cost", Economic Inquiry 26(3), 461-70.

[10] Norris, Pippa (2001): British Parliamentary Constituency Database 1992-001, release 1.2. available at http://ksghome.harvard.edu/ pnorris/Data/Data.htm.

[11] Norton, Philip and David M. Wood, [1993], Back from Westminster: British Members of Parliament and Their Constituents, Lexington, Kentucky: The University of Kentucky Press. 
[12] Padro' i Miguel, Gerard and James M. Snyder (2004): Legislative Effectiveness and Legislative Life, mimeo MIT.

[13] Parker, Glenn R, and Stephen C. Powers (2002): Searching for symptoms of political shirking: Congressional foreign travel, Public Choice, 110, 173-191.

[14] Putnam, Robert (1993): Making Democracy Work: Civic Traditions in Modern Italy, Princeton: Princeton University Press.

[15] Shiller, Wendy J. (1995): Senators as Political Entrepreneurs: Using Bill Sponsorship to Shape Legislative Agendas, American Journal of Political Science, 39, 186-203.

[16] Solt, Frederick (2004): Civics or Structure? Revisiting the Origins of Democratic Quality in the Italian Regions, British Journal of Political Science, 34, 123-135.

[17] Wawro, Gregory (2002): Legislative Entrepreneurship in the U.S. House of Representatives. Ann Arbor: University of Michigan Press. 


\section{Data Appendix: definitions and sources}

\subsection{MPs' Allowance Expenditure}

The data on expenses claims have been released under the Freedom of Information Act by the Parliament and are available at the following web page: http://www.parliament.uk/site_information/allowances.cfm. The following description of expense allowances are taken from the House of Commons web page:

A. Additional Costs Allowance (ACA)

This is paid to reimburse Members for necessary costs incurred when staying overnight away from their main home for the purpose of performing parliamentary duties. Inner London Members do not receive this allowance. Until February 2004, Ministers and certain paid office holders were deemed to have their main home in London and could claim this allowance only for overnight stays in the constituency.

\section{B. London Supplement}

Inner London Members receive the London Supplement instead of the ACA. Outer London Members may choose between the ACA and the London Supplement. Ministers who do not live in official accommodation and certain office holders automatically receive the London Supplement with their salary. London Supplement is subject to income tax and national insurance.

C. Incidental Expenses Provision (IEP)

This is paid to meet the costs of accommodation for office or surgery use; equipment and supplies for office or surgery; work commissioned or other services; and certain travel and communications.

D. Staffing Allowance

This is paid to enable Members to engage staff. The IEP can also be used to cover certain staff related costs. The Staffing Allowance varies according to the number of staff based in London. London Members automatically receive the higher figure.

\section{E. Members' Travel}

This is the total cost of travel on parliamentary business within the UK plus certain European travel. Members' travel does not include travel on parliamentary delegation business or select committee visits.

Certain elements of the travel allowances are taxable. More information about the various categories of travel and transport can be found on the Parliament web page. 


\section{F. Members' Staff Travel}

Until December 2003 Each Member was allowed a total of eighteen single journeys per calendar year between Westminster and the constituency, shared by all employees. This increased to 30 single journeys for the period 1 January 2004 to 30 March 2005.

\section{G1. Centrally Purchased Stationery}

This column sets out the cost of stationery items ordered from a central supplier. This includes stationery with prepaid postage for use in direct connection with a Member's parliamentary duties; the House of Commons is charged separately for the associated postage costs.

The figures given for each Member for 2001-02 and 2002-03 do not include any postage costs. The figures for 2003-04 include the postage costs for each Member.

G2. Postage Associated with the use of Centrally Purchased Stationery (2003-04 only)

This column sets out the cost of postage associated with the use of stationery with prepaid postage ordered from the central supplier for use in direct connection with a Member's parliamentary duties.

\section{H. Centrally Provided Computer Equipment}

This column sets out the cost of equipment supplied on loan to each Member. The provision allows for up to one laptop, three desktop PCs, two CD rewriters and one or two printers, depending on the specification required. The costs show the asset value spread over a four-year period.

\section{Other Costs}

This column sets out costs incurred from central budgets, including the temporary secretarial allowance which pays for additional help when staff are absent due to sickness or maternity leave; central contributions to security costs for the office; exceptional needs support (from March 2004) which provides for short term additional help to Members whose constituencies have particular problems; ill-health retirement grant; and winding-up allowance payable to defeated or retiring Members or representatives of deceased Members after the date on which they cease to be Members of Parliament.

The aggregates used in the regressions are defined as follows (all variables are expressed as annual averages):

- Total: the sum of all expenses.

- Travel: $\mathrm{E}+\mathrm{F}$ 
- Staff: D

- Other: $\mathrm{C}+\mathrm{G} 1+\mathrm{G} 2+\mathrm{H}+\mathrm{I}$

\subsection{Parliamentary attendance}

Attendance is constructed from parliamentary division information provided by Firth and Spirling (2003). The total attendance variable measures the number of divisions for which an MP cast her/his vote during the period June 2001-March 2004. The percentage attendance variable is measured as

$($ total attendance $\times 100) / 876$

where 876 is the total number of divisions (votes) in the period considered.

Cost per vote is measured as the total expenses claimed in the period March 2001 - June 2004 divided by the number of divisions attended by an MP.

These variables do not include the speaker and deputy speakers of the House of Commons.

\subsection{Other variables}

- The variables regarding the size of the electorate (number of potential voters), turnout (percentage of actual voters) and marginality (dummy equal to 1 for constituencies in which the winning party had less than $10 \%$ lead over the runner up in the 2001 general election) have been taken from the British Parliamentary Constituency Database, compiled and edited by Pippa Norris and available at

http://ksghome.harvard.edu/ pnorris/Data/Data.htm.

- The distance of a constituency from Westminster is measured in miles and is referred to the main town in each constituency. It has been derived from the AA website.

- Income is taken from the Office for National Statistics and it is disaggregated at the level NUTS 2. NUTS stands for Nomenclature of Territorial Units for Statistics and is a subdivision of the UK devised by Eurostat. NUTS 2 corresponds, although imperfectly, to counties. 
- Information on individual characteristics, party affiliation, cabinet and shadow cabinet membership have been collected by the authors using various sources. Conservative, Labour, Lib-Dem and Other Party are dummy variables equal to one when the MP is a member of the named party. Cabinet membership (and shadow cabinet membership) has been constructed as the share of time (with units expressed in months) during which the MP has been a member of cabinet (or the shadow cabinet) in the period June 2001-March 2004. Gender is a dummy variable equal to 1 for female MPs. Age is expressed in years and refers to the age in the year 2001. Experience is expressed as the number of years already spent in parliament by an MP at the moment of her/his election in 2001. Degree is a dummy variable equal to 1 for MPs that have obtained a university degree. Oxbridge is a dummy variable equal to 1 if the degree has been obtained from either Oxford or Cambridge University. Retiring is a dummy equal to 1 for MPs that, at any point during the 2001-2005 legislature, announced their intention not to be candidate in the next general election. 
Table 1: Summary Statistics

\begin{tabular}{|c|c|c|c|c|c|}
\hline$\overline{\text { Variable }}$ & "Obs & Mean & Std. Dev. & 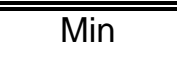 & 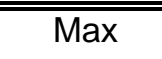 \\
\hline Total claims & 638 & 105849.3 & 11772.25 & 62264.67 & 138717.7 \\
\hline Travel expenses & 638 & 10354.12 & 6259.1 & 0 & 39637.33 \\
\hline Staff expenses & 638 & 58546.44 & 5836.669 & 35214.33 & 72189.34 \\
\hline Other expenses & 638 & 21206.71 & 4695.632 & 5792.669 & 40158.34 \\
\hline Distance & 639 & 147.8326 & 132.2461 & 0 & 702 \\
\hline Income & 639 & 15625.47 & 2246.883 & 12913 & 19641 \\
\hline Size & 639 & 67389.44 & 8583.635 & 21807 & 106305 \\
\hline Conservative & 639 & .258216 & .4379962 & 0 & 1 \\
\hline Labour & 639 & .6416275 & .479898 & 0 & 1 \\
\hline Liberal-Democratic & 639 & .0829421 & 2760107 & 0 & 1 \\
\hline Other party & 639 & .0156495 & .1242123 & 0 & 1 \\
\hline Cabinet member & 639 & .031205 & .1638036 & 0 & 1 \\
\hline Shadow Cab. Member & 639 & 0.0354617 & .1630087 & 0 & 1 \\
\hline Turnout & 639 & 58.97622 & 6.392356 & 34.08262 & 72.27435 \\
\hline Marginal & 639 & .1924883 & .3945633 & 0 & 1 \\
\hline Gender & 639 & .1784038 & .3831522 & 0 & 1 \\
\hline Age & 639 & 50.12363 & 8.656926 & 29 & 79 \\
\hline Experience & 639 & 8.061033 & 7.470173 & 0 & 39 \\
\hline Degree & 639 & .7887324 & .4085276 & 0 & 1 \\
\hline Oxbridge & 638 & .2601881 & .4390813 & 0 & 1 \\
\hline Retiring & 639 & .1298905 & .3364462 & 0 & 1 \\
\hline Attendance (perc.) & 634 & 69.01791 & 13.21894 & 7.762557 & 93.94977 \\
\hline Attendance (total) & 634 & 604.5969 & 115.7979 & 68 & 823 \\
\hline Cost per Vote & 634 & 556.4027 & 215.4933 & 257.292 & 3360.059 \\
\hline
\end{tabular}


Table 2: Total average claims per year (2001-04)

\begin{tabular}{|c|c|c|c|}
\hline Dep. Variable & $\begin{array}{c}(1) \\
\text { Total claims } \\
\end{array}$ & $\begin{array}{c}(2) \\
\text { Total claims } \\
\end{array}$ & $\begin{array}{c}(3) \\
\text { Total claims } \\
\end{array}$ \\
\hline Distance & $\begin{array}{c}41.087 \\
(4.62)^{\star * \star}\end{array}$ & $\begin{array}{c}32.581 \\
(3.56)^{\star * *}\end{array}$ & $\begin{array}{c}31.303 \\
(3.53)^{\star * *}\end{array}$ \\
\hline Income & $\begin{array}{l}-0.261 \\
(0.61)\end{array}$ & $\begin{array}{l}-0.481 \\
(1.07)\end{array}$ & $\begin{array}{l}-0.527 \\
(1.19)\end{array}$ \\
\hline Size & $\begin{array}{l}0.027 \\
(0.39)\end{array}$ & $\begin{array}{l}-0.031 \\
(0.46)\end{array}$ & $\begin{array}{l}-0.014 \\
(0.21)\end{array}$ \\
\hline Conservatives & & $\begin{array}{c}-1,881.664 \\
(1.42)\end{array}$ & $\begin{array}{c}-436.544 \\
(0.33)\end{array}$ \\
\hline Liberal-Democratic & & $\begin{array}{c}-1,053.328 \\
(0.77)\end{array}$ & $\begin{array}{c}-1,222.235 \\
(0.86)\end{array}$ \\
\hline Other Party & & $\begin{array}{c}938.230 \\
(0.23)\end{array}$ & $\begin{array}{c}-1,605.525 \\
(0.39)\end{array}$ \\
\hline Cabinet Member & & $\begin{array}{c}-10,404.230 \\
(3.56)^{\star \star *}\end{array}$ & $\begin{array}{c}-8,865.197 \\
(2.85)^{\star \star \star}\end{array}$ \\
\hline Shadow Cab. Member & & $\begin{array}{c}520.634 \\
(0.19)\end{array}$ & $\begin{array}{c}-122.208 \\
(0.04)\end{array}$ \\
\hline Marginal seat & & $\begin{array}{c}1,532.540 \\
(1.36)\end{array}$ & $\begin{array}{c}861.041 \\
(0.78)\end{array}$ \\
\hline Turnout & & $\begin{array}{l}310.216 \\
(3.35)^{\star * *}\end{array}$ & $\begin{array}{l}208.211 \\
(2.24)^{\star \star}\end{array}$ \\
\hline Gender & & & $\begin{array}{c}-1,074.762 \\
(1.04)\end{array}$ \\
\hline Age & & & $\begin{array}{l}-277.605 \\
(4.99)^{\star \star \star}\end{array}$ \\
\hline Experience & & & $\begin{array}{c}-151.481 \\
(1.94)^{\star}\end{array}$ \\
\hline Degree & & & $\begin{array}{c}144.327 \\
(0.14)\end{array}$ \\
\hline Oxbridge & & & $\begin{array}{c}-2,572.763 \\
(2.44)^{\star \star}\end{array}$ \\
\hline Constant & $\begin{array}{c}102,054.540 \\
(11.91)^{\star \star \star}\end{array}$ & $\begin{array}{c}92,919.207 \\
(10.65)^{\star \star *}\end{array}$ & $\begin{array}{c}114,332.524 \\
(12.67)^{\star \star *}\end{array}$ \\
\hline $\begin{array}{l}\text { Observations } \\
\text { R-squared }\end{array}$ & $\begin{array}{l}638 \\
0.17 \\
\end{array}$ & $\begin{array}{l}638 \\
0.22 \\
\end{array}$ & $\begin{array}{l}638 \\
0.29 \\
\end{array}$ \\
\hline
\end{tabular}

All regressions contain 11 dummy variables for the standard regions

Robust t statistics in parentheses

${ }^{*}$ significant at $10 \%$; ${ }^{* \star}$ significant at $5 \% ;{ }^{* \star *}$ significant at $1 \%$ 
Table 3: Top 10 spenders (average 2001-2004)

\begin{tabular}{lll}
\hline \hline Member & Constituency & Amount \\
\hline & & \\
Eric Joyce & Falkirk West & 138,718 \\
Claire Curtis-Thomas & Crosby & 137,891 \\
Angus Robertson & Moray & 135,335 \\
Mohammad Sarwar & Glasgow Govan & 134,720 \\
Peter Duncan & Galloway \& Upper Nithsdale & 133,447 \\
Paul Farrelly & Newcastle-under-Lyme & 131,851 \\
Doug Henderson & Newcastle upon Tyne North & 131,354 \\
Anne Picking & East Lothian & 131,109 \\
Alistair Carmichael & Orkney \& Shetland & 130,929 \\
Jim Sheridan & Renfrewshire West & 130,908 \\
\hline \hline
\end{tabular}




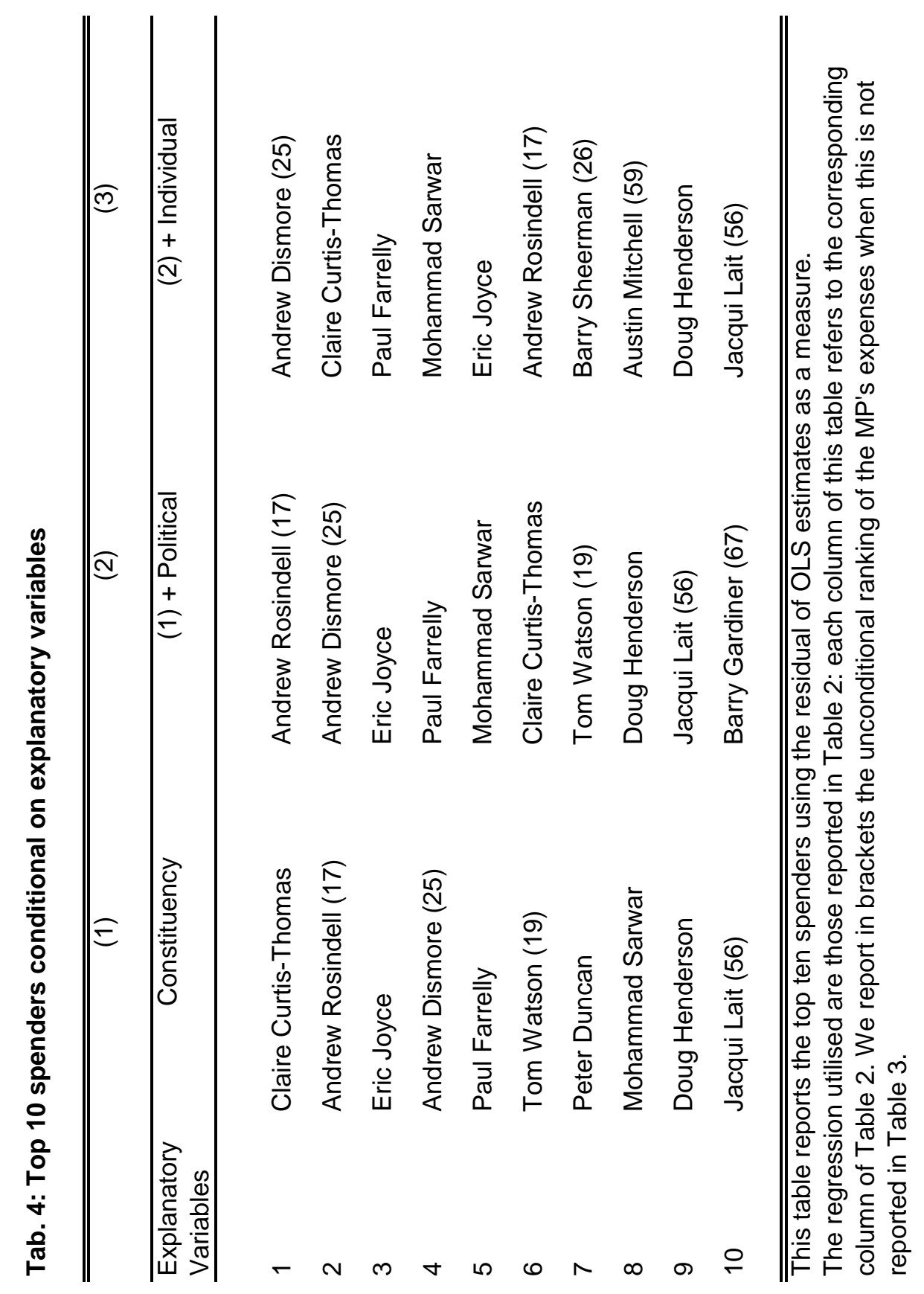


Table 5: Travel, staff and other expenses

\begin{tabular}{|c|c|c|c|}
\hline Dep. Variable & $\begin{array}{c}(1) \\
\text { Travel }\end{array}$ & $\begin{array}{c}(2) \\
\text { Staff } \\
\end{array}$ & $\begin{array}{c}(3) \\
\text { Other }\end{array}$ \\
\hline Distance & $\begin{array}{c}18.983 \\
(4.71)^{\star \star \star}\end{array}$ & $\begin{array}{l}7.683 \\
(1.70)^{*}\end{array}$ & $\begin{array}{l}3.130 \\
(0.94)\end{array}$ \\
\hline Income & $\begin{array}{c}-0.441 \\
(3.19)^{\star * \star}\end{array}$ & $\begin{array}{l}0.245 \\
(1.09)\end{array}$ & $\begin{array}{l}-0.146 \\
(0.77)\end{array}$ \\
\hline Size & $\begin{array}{l}-0.053 \\
(2.33)^{\star *}\end{array}$ & $\begin{array}{l}0.033 \\
(1.07)\end{array}$ & $\begin{array}{l}0.022 \\
(0.68)\end{array}$ \\
\hline Conservative & $\begin{array}{c}34.094 \\
(0.08)\end{array}$ & $\begin{array}{c}742.866 \\
(1.15)\end{array}$ & $\begin{array}{c}-2,380.012 \\
(4.42)^{\star \star *}\end{array}$ \\
\hline Liberal-Democratic & $\begin{array}{c}-548.978 \\
(0.91)\end{array}$ & $\begin{array}{c}1,549.347 \\
(2.37)^{\star *}\end{array}$ & $\begin{array}{c}-905.268 \\
(1.55)\end{array}$ \\
\hline Other Party & $\begin{array}{c}1,246.412 \\
(0.95)\end{array}$ & $\begin{array}{c}-3,809.924 \\
(1.93)^{\star}\end{array}$ & $\begin{array}{c}-32.463 \\
(0.01)\end{array}$ \\
\hline Cabinet Member & $\begin{array}{c}-6,571.627 \\
(6.44)^{\star \star \star}\end{array}$ & $\begin{array}{c}-3,079.584 \\
(1.61)\end{array}$ & $\begin{array}{c}-337.827 \\
(0.30)\end{array}$ \\
\hline Shadow Cab. Member & $\begin{array}{c}397.550 \\
(0.33)\end{array}$ & $\begin{array}{c}-491.733 \\
(0.33)\end{array}$ & $\begin{array}{c}-48.667 \\
(0.07)\end{array}$ \\
\hline Marginal Seat & $\begin{array}{c}110.157 \\
(0.28)\end{array}$ & $\begin{array}{l}90.067 \\
(0.18)\end{array}$ & $\begin{array}{l}80.714 \\
(0.18)\end{array}$ \\
\hline Turnout & $\begin{array}{l}72.403 \\
(2.02)^{* *}\end{array}$ & $\begin{array}{c}-35.981 \\
(0.85)\end{array}$ & $\begin{array}{l}81.254 \\
(2.17)^{\star *}\end{array}$ \\
\hline Gender & $\begin{array}{c}-1,012.838 \\
(2.54)^{\star *}\end{array}$ & $\begin{array}{c}228.055 \\
(0.44)\end{array}$ & $\begin{array}{c}447.719 \\
(1.05)\end{array}$ \\
\hline Age & $\begin{array}{l}-4.444 \\
(0.21)\end{array}$ & $\begin{array}{l}-89.547 \\
(3.26)^{\star * *}\end{array}$ & $\begin{array}{l}-142.837 \\
(5.82)^{\star \star \star}\end{array}$ \\
\hline Experience & $\begin{array}{l}-13.658 \\
(0.53)\end{array}$ & $\begin{array}{c}26.042 \\
(0.61)\end{array}$ & $\begin{array}{l}-120.598 \\
(3.61)^{\star \star \star}\end{array}$ \\
\hline Degree & $\begin{array}{c}-609.858 \\
(1.44)\end{array}$ & $\begin{array}{c}665.913 \\
(1.30)\end{array}$ & $\begin{array}{c}268.633 \\
(0.67)\end{array}$ \\
\hline Oxbridge & $\begin{array}{c}-412.208 \\
(1.13)\end{array}$ & $\begin{array}{c}-585.157 \\
(1.09)\end{array}$ & $\begin{array}{c}-502.667 \\
(1.15)\end{array}$ \\
\hline Constant & $\begin{array}{c}15,023.799 \\
(5.01)^{\star * *}\end{array}$ & $\begin{array}{c}57,209.357 \\
(13.27)^{\star * *}\end{array}$ & $\begin{array}{c}25,428.286 \\
(6.65)^{\star * *}\end{array}$ \\
\hline $\begin{array}{l}\text { Observations } \\
\text { R-squared }\end{array}$ & $\begin{array}{l}638 \\
0.65 \\
\end{array}$ & $\begin{array}{l}638 \\
0.26 \\
\end{array}$ & $\begin{array}{l}638 \\
0.26 \\
\end{array}$ \\
\hline
\end{tabular}

All regressions contain 11 dummy variables for the standard regions

Robust t statistics in parentheses

${ }^{*}$ significant at $10 \%$; ${ }^{* *}$ significant at $5 \% ;{ }^{* * *}$ significant at $1 \%$ 
Table 6: Do retiring MPs behave differently?

\begin{tabular}{|c|c|c|c|c|}
\hline Dep. Variable & $\begin{array}{l}(1) \\
\text { Total } \\
\end{array}$ & $\begin{array}{c}(2) \\
\text { Travel } \\
\end{array}$ & $\begin{array}{c}(3) \\
\text { Staff }\end{array}$ & $\begin{array}{c}(4) \\
\text { Other }\end{array}$ \\
\hline Distance & $\begin{array}{c}31.491 \\
(3.55)^{\star \star \star}\end{array}$ & $\begin{array}{c}18.940 \\
(4.69)^{\star \star \star}\end{array}$ & $\begin{array}{l}7.758 \\
(1.71)^{\star}\end{array}$ & $\begin{array}{l}3.281 \\
(0.99)\end{array}$ \\
\hline Income & $\begin{array}{l}-0.535 \\
(1.21)\end{array}$ & $\begin{array}{c}-0.439 \\
(3.18)^{\star \star \star}\end{array}$ & $\begin{array}{l}0.243 \\
(1.08)\end{array}$ & $\begin{array}{l}-0.152 \\
(0.81)\end{array}$ \\
\hline Size & $\begin{array}{l}-0.019 \\
(0.29)\end{array}$ & $\begin{array}{l}-0.052 \\
(2.26)^{\star *}\end{array}$ & $\begin{array}{l}0.030 \\
(0.99)\end{array}$ & $\begin{array}{l}0.017 \\
(0.55)\end{array}$ \\
\hline Conservatives & $\begin{array}{c}-526.617 \\
(0.40)\end{array}$ & $\begin{array}{l}54.867 \\
(0.12)\end{array}$ & $\begin{array}{c}707.127 \\
(1.09)\end{array}$ & $\begin{array}{c}-2,452.128 \\
(4.56)^{\star \star \star}\end{array}$ \\
\hline Liberal-Democratic & $\begin{array}{c}-1,256.517 \\
(0.88)\end{array}$ & $\begin{array}{c}-541.072 \\
(0.90)\end{array}$ & $\begin{array}{c}1,535.745 \\
(2.33)^{\star *}\end{array}$ & $\begin{array}{c}-932.715 \\
(1.63)\end{array}$ \\
\hline Other parties & $\begin{array}{c}-1,835.131 \\
(0.45)\end{array}$ & $\begin{array}{c}1,299.365 \\
(0.98)\end{array}$ & $\begin{array}{c}-3,901.025 \\
(1.98)^{\star *}\end{array}$ & $\begin{array}{c}-216.295 \\
(0.09)\end{array}$ \\
\hline Cabinet Member & $\begin{array}{c}-9,145.673 \\
(2.94)^{\star \star \star}\end{array}$ & $\begin{array}{c}-6,506.941 \\
(6.37)^{\star \star \star}\end{array}$ & $\begin{array}{c}-3,190.869 \\
(1.67)^{\star}\end{array}$ & $\begin{array}{c}-562.388 \\
(0.50)\end{array}$ \\
\hline Shadow Cab. Member & $\begin{array}{c}-377.824 \\
(0.14)\end{array}$ & $\begin{array}{c}456.502 \\
(0.38)\end{array}$ & $\begin{array}{c}-593.155 \\
(0.40)\end{array}$ & $\begin{array}{c}-253.324 \\
(0.36)\end{array}$ \\
\hline Marginal Seat & $\begin{array}{c}913.688 \\
(0.83)\end{array}$ & $\begin{array}{l}98.015 \\
(0.25)\end{array}$ & $\begin{array}{c}110.956 \\
(0.22)\end{array}$ & $\begin{array}{c}122.866 \\
(0.28)\end{array}$ \\
\hline Turnout & $\begin{array}{l}212.257 \\
(2.28)^{\star *}\end{array}$ & $\begin{array}{l}71.470 \\
(2.00)^{\star \star}\end{array}$ & $\begin{array}{c}-34.376 \\
(0.81)\end{array}$ & $\begin{array}{l}84.493 \\
(2.25)^{\star *}\end{array}$ \\
\hline Gender & $\begin{array}{c}-958.822 \\
(0.93)\end{array}$ & $\begin{array}{c}-1,039.577 \\
(2.60)^{\star \star \star}\end{array}$ & $\begin{array}{c}274.057 \\
(0.54)\end{array}$ & $\begin{array}{c}540.546 \\
(1.27)\end{array}$ \\
\hline Age & $\begin{array}{l}-262.052 \\
(4.69)^{\star * *}\end{array}$ & $\begin{array}{l}-8.031 \\
(0.36)\end{array}$ & $\begin{array}{l}-83.376 \\
(3.04)^{\star * *}\end{array}$ & $\begin{array}{l}-130.384 \\
(5.37)^{\star \star *}\end{array}$ \\
\hline Experience & $\begin{array}{c}-137.028 \\
(1.72)^{*}\end{array}$ & $\begin{array}{c}-16.991 \\
(0.66)\end{array}$ & $\begin{array}{l}31.776 \\
(0.73)\end{array}$ & $\begin{array}{l}-109.027 \\
(3.22)^{\star \star \star}\end{array}$ \\
\hline Degree & $\begin{array}{c}108.979 \\
(0.10)\end{array}$ & $\begin{array}{c}-601.705 \\
(1.42)\end{array}$ & $\begin{array}{c}651.888 \\
(1.27)\end{array}$ & $\begin{array}{c}240.332 \\
(0.60)\end{array}$ \\
\hline Oxbridge & $\begin{array}{c}-2,472.154 \\
(2.34)^{\star *}\end{array}$ & $\begin{array}{c}-435.411 \\
(1.18)\end{array}$ & $\begin{array}{c}-545.238 \\
(1.03)\end{array}$ & $\begin{array}{c}-422.115 \\
(0.97)\end{array}$ \\
\hline Retiring & $\begin{array}{c}-2,045.862 \\
(1.46)\end{array}$ & $\begin{array}{c}471.833 \\
(1.03)\end{array}$ & $\begin{array}{c}-811.742 \\
(1.15)\end{array}$ & $\begin{array}{c}-1,637.998 \\
(3.22)^{\star * *}\end{array}$ \\
\hline Constant & $\begin{array}{c}113,924.723 \\
(12.73)^{\star \star *}\end{array}$ & $\begin{array}{c}15,117.850 \\
(5.02)^{* * *}\end{array}$ & $\begin{array}{c}57,047.552 \\
(13.24)^{\star * *}\end{array}$ & $\begin{array}{c}25,101.785 \\
(6.66)^{\star \star \star}\end{array}$ \\
\hline $\begin{array}{l}\text { Observations } \\
\text { R-squared }\end{array}$ & $\begin{array}{l}638 \\
0.29\end{array}$ & $\begin{array}{l}638 \\
0.65\end{array}$ & $\begin{array}{l}638 \\
0.26\end{array}$ & $\begin{array}{l}638 \\
0.28\end{array}$ \\
\hline
\end{tabular}

All regressions contain 11 dummy variables for the standard regions

Robust $t$ statistics in parentheses

${ }^{*}$ significant at $10 \%$; ${ }^{* *}$ significant at $5 \% ;{ }^{* * *}$ significant at $1 \%$ 
Table 7: Parliamentary Attendance and Cost per Vote

\begin{tabular}{|c|c|c|c|c|}
\hline Dependent Variable & $\begin{array}{c}(1) \\
\text { Attendance } \\
\end{array}$ & $\begin{array}{c}\text { (2) } \\
\text { Cost per Vote } \\
\end{array}$ & $\begin{array}{c}\text { (3) } \\
\text { Cost per Vote } \\
\end{array}$ & $\begin{array}{c}(4) \\
\text { Cost per Vote }\end{array}$ \\
\hline Distance & $\begin{array}{l}0.013 \\
(1.46)\end{array}$ & $\begin{array}{l}0.219 \\
(1.39)\end{array}$ & $\begin{array}{l}0.119 \\
(0.91)\end{array}$ & $\begin{array}{l}0.084 \\
(0.69)\end{array}$ \\
\hline Income & $\begin{array}{l}0.000 \\
(0.71)\end{array}$ & $\begin{array}{r}-0.000 \\
(0.01)\end{array}$ & $\begin{array}{l}-0.006 \\
(0.94)\end{array}$ & $\begin{array}{l}-0.008 \\
(1.16)\end{array}$ \\
\hline Size & $\begin{array}{l}0.000 \\
(0.61)\end{array}$ & $\begin{array}{r}-0.000 \\
(0.51)\end{array}$ & $\begin{array}{l}-0.001 \\
(0.76)\end{array}$ & $\begin{array}{r}-0.000 \\
(0.34)\end{array}$ \\
\hline Conservatives & $\begin{array}{c}-8.596 \\
(6.55)^{\star \star \star}\end{array}$ & & $\begin{array}{c}71.364 \\
(4.64)^{\star * *}\end{array}$ & $\begin{array}{c}53.558 \\
(3.11)^{\star * *}\end{array}$ \\
\hline Liberal-Democratic & $\begin{array}{c}-4.735 \\
(2.77)^{* * *}\end{array}$ & & $\begin{array}{c}17.639 \\
(0.84)\end{array}$ & $\begin{array}{c}16.433 \\
(0.76)\end{array}$ \\
\hline Other Party & $\begin{array}{l}-14.339 \\
(4.45)^{\star * *}\end{array}$ & & $\begin{array}{l}122.497 \\
(2.64)^{\star * *}\end{array}$ & $\begin{array}{l}123.291 \\
(2.86)^{\star * *}\end{array}$ \\
\hline Cabinet Member & $\begin{array}{l}-28.541 \\
(6.60)^{\star * *}\end{array}$ & & $\begin{array}{l}571.835 \\
(2.90)^{\star * *}\end{array}$ & $\begin{array}{l}544.453 \\
(2.85)^{\star * *}\end{array}$ \\
\hline Shadow cab. Member & $\begin{array}{l}-4.674 \\
(2.14)^{\star *}\end{array}$ & & $\begin{array}{c}34.820 \\
(1.12)\end{array}$ & $\begin{array}{c}30.720 \\
(0.96)\end{array}$ \\
\hline Marginal Seat & $\begin{array}{l}-0.843 \\
(0.81)\end{array}$ & & $\begin{array}{l}4.380 \\
(0.34)\end{array}$ & $\begin{array}{l}11.047 \\
(0.89)\end{array}$ \\
\hline Turnout & $\begin{array}{l}0.017 \\
(0.15)\end{array}$ & & $\begin{array}{l}1.062 \\
(0.52)\end{array}$ & $\begin{array}{l}2.196 \\
(1.06)\end{array}$ \\
\hline Gender & $\begin{array}{l}-2.880 \\
(2.24)^{* *}\end{array}$ & & & $\begin{array}{c}13.993 \\
(0.76)\end{array}$ \\
\hline Age & $\begin{array}{l}0.085 \\
(1.25)\end{array}$ & & & $\begin{array}{c}-3.177 \\
(3.38)^{\star \star \star}\end{array}$ \\
\hline Experience & $\begin{array}{c}-0.597 \\
(7.66)^{\star \star \star}\end{array}$ & & & $\begin{array}{c}6.760 \\
(5.14)^{\star * *}\end{array}$ \\
\hline Degree & $\begin{array}{l}-0.654 \\
(0.53)\end{array}$ & & & $\begin{array}{l}-8.632 \\
(0.50)\end{array}$ \\
\hline Oxbridge & $\begin{array}{l}-0.978 \\
(0.91)\end{array}$ & & & $\begin{array}{l}-0.124 \\
(0.01)\end{array}$ \\
\hline Retiring & $\begin{array}{l}-3.988 \\
(2.51)^{* *}\end{array}$ & & & $\begin{array}{c}19.419 \\
(0.88)\end{array}$ \\
\hline Constant & $\begin{array}{c}64.221 \\
(6.20)^{\star * \star}\end{array}$ & $\begin{array}{l}557.557 \\
(4.98)^{\star * \star}\end{array}$ & $\begin{array}{l}586.251 \\
(4.81)^{\star * *}\end{array}$ & $\begin{array}{l}629.156 \\
(4.57)^{\star \star \star}\end{array}$ \\
\hline Observations & 634 & 634 & 634 & 634 \\
\hline R-squared & 0.36 & 0.05 & 0.25 & 0.28 \\
\hline
\end{tabular}

All regressions contain 11 dummy variables for the standard regions

Robust t statistics in parentheses

${ }^{*}$ significant at $10 \%$; ${ }^{\star \star}$ significant at $5 \% ;{ }^{* \star *}$ significant at $1 \%$ 
Tab 8: The most expensive votes in parliament (2001-2004)

\begin{tabular}{lllll}
\hline \hline \multicolumn{1}{c}{$(1)$} & & \multicolumn{1}{c}{$(2)$} & \\
\hline \hline & Unconditional & Cost & Excluding government members & Cost \\
\hline & Tony Blair & 3360 & George Galloway (333) & 1491 \\
2 & Gordon Brown & 3114 & Gwineth Dunwoody (450) & 1187 \\
3 & Jack Straw & 2043 & Michael Mates (296) & 1070 \\
4 & Brian Wilson & 1596 & Alex Salmond (15) & 1043 \\
5 & George Galloway & 1491 & Nigel Jones (403) & 1012 \\
6 & Clare Short & 1260 & Claire Curtis-Thomas (2) & 967 \\
7 & Jane Kennedy & 1243 & Peter Duncan (5) & 929 \\
8 & Gwyneth Dunwoody & 1187 & Alan Meale (37) & 922 \\
9 & Michael Mates & 1070 & Angus Robertson (3) & 900 \\
10 & Alex Salmond & 1043 & Debra Shipley (197) & 843 \\
\hline \hline
\end{tabular}

In column 2 we report in brackets the position in the total expense ranking. 